\title{
Remittances: An Automatic Output Stabilizer?
}

\author{
Ralph Chami, Dalia Hakura, and \\ Peter Montiel
}





\title{
IMF Working Paper
}

IMF Institute

\section{Remittances: An Automatic Output Stabilizer?}

\author{
Prepared by Ralph Chami, Dalia Hakura, and Peter Montiel
}

Authorized for distribution by Ralph Chami

April 2009

\begin{abstract}

\section{This Working Paper should not be reported as representing the views of the IMF.}

The views expressed in this Working Paper are those of the author(s) and do not necessarily represent those of the IMF or IMF policy. Working Papers describe research in progress by the author(s) and are published to elicit comments and to further debate.

Remittance flows appear to be falling worldwide for the first time in decades as a result of the ongoing financial turmoil. It is suspected that the drop in remittance income into developing and emerging markets will have a destabilizing effect on these economies. The paper estimates the impact of remittances on output stability for countries that are dependent on these income flows. Using a sample of 70 countries, including 16 advanced economies and 54 developing countries, we find robust evidence that remittances have a negative effect on output growth volatility of recipient countries. This result supports the notion that remittance flows are a stabilizing influence on output. Thus, the fall in remittances precipitated by the ongoing global financial crisis could potentially increase output variability in recipient countries. This would present a hard challenge for governments in those countries already suffering from the crisis: they must resort to an already stressed and limited set of policy instruments, such as fiscal policy, to counter the resulting adverse economic and social impacts of lower remittances.
\end{abstract}

JEL Classification Numbers:D02, D64, F02, F22, F24

Keywords: Remittances, output volatility, financial crisis, stability, poverty

Author's E-Mail Address: Rchami@imf.org, Dhakura@imf.org, and

Peter.J.Montiel@williams.edu 


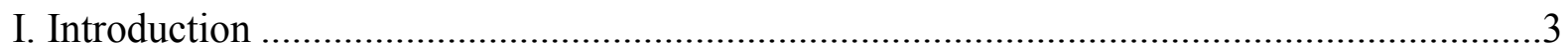

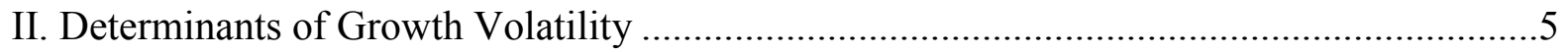

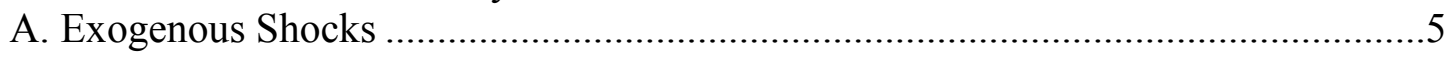

B. Persistent Country Characteristics ............................................................ 6

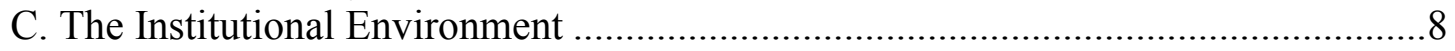

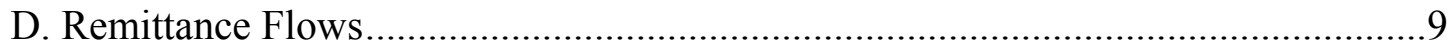

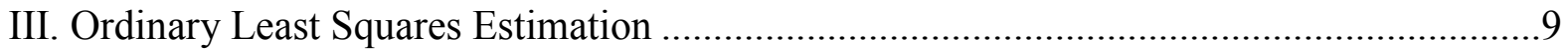

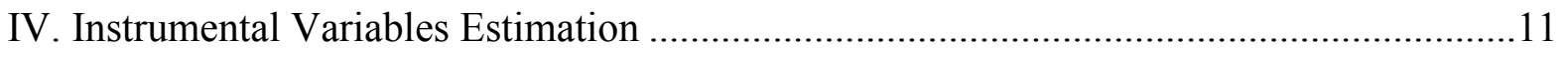

V. Generalized Method of Moments Dynamic Panel Estimation...........................................12

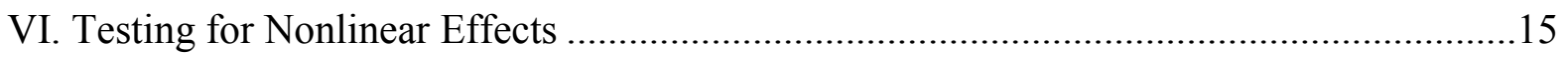

VII. An Application: Remittances and Output Stability in the Middle East and North Africa16

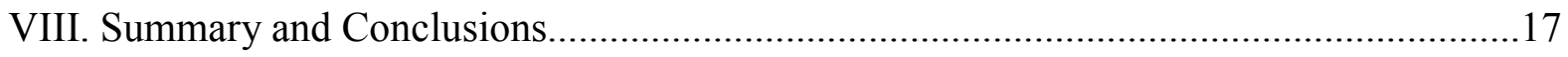

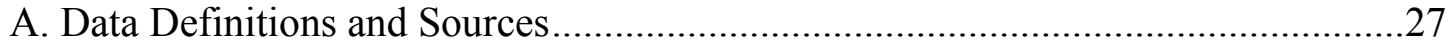

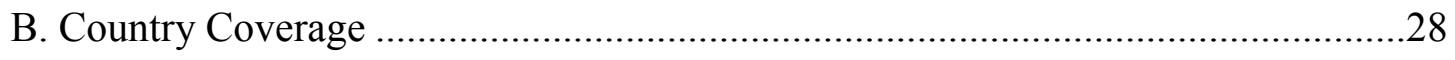

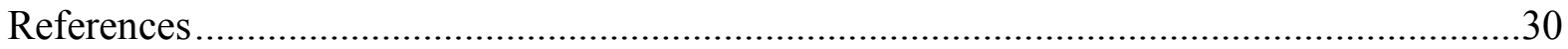

Tables

1. Output Volatility and Workers Remittances............................................................. 19

2. Descriptive Statistics of Dependent and Explanatory Variables $1970-2004$.................20

3. Ordinary Least Squares and Instrumental Variables Regression Results .........................21

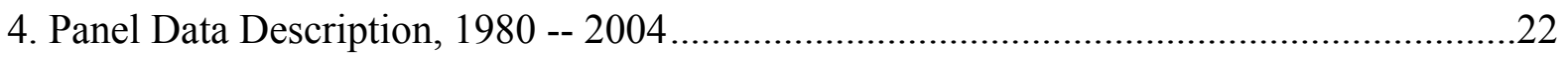

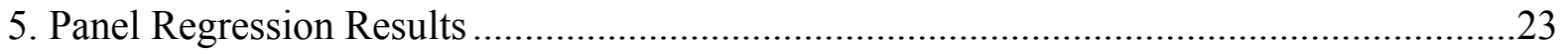

6. Nonlinear Ordinary Least Squares and Instrumental Variables Regression Results ...........24

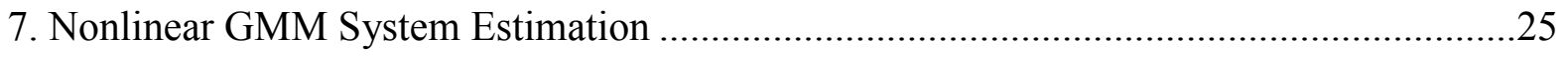

8. Estimated Impact of Remittances on Volatility .......................................................26

Appendixes

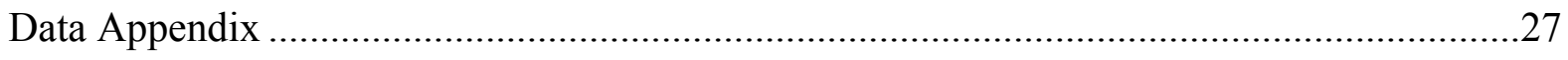

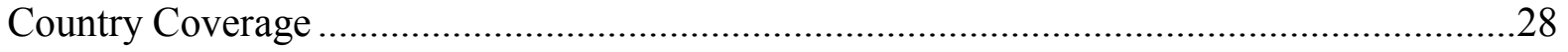




\section{INTRODUCTION}

Policymakers, in their efforts to limit the impact of the ongoing financial crisis on their countries, have been feverishly trying to identify the channels through which the ongoing financial crisis is spreading and affecting the economies around the globe. Some have already been identified: the massive losses by banks coupled with the heightened risk aversion among investors leading to a contraction in credit, the drop in global demand and its implication for the income of exporters, and the outflow of foreign capital from emerging and developing countries, with its destabilizing effect on private and public finances in these economies.

The crisis, however, could easily turn into a global humanitarian crisis, due to a potentially bigger threat to the well-being of emerging and developing countries. Remittances - the cash that migrant workers send to their families back home - appear to be falling, for the first time in decades. There are already signs that the global slowdown is affecting the demand for migrant labor in both the industrialized and the Persian Gulf countries, the main sources of remittance income. According the to a recent World Bank report, remittance flows are estimated to fall by 5 to 8 percent in 2009. Other studies report that remittances to Philippines, Mexico, the Middle East and Africa have dropped considerably. For example, Cali, Massa, and te Verde (2008) report that remittances to Kenya have dropped by $38 \%$ for 2008. If this trend continues, which is likely given the depth of the impending recession, the impact on the recipient countries could be severe.

Although each remittance is small, together they are huge, especially in comparison to the size of the economies that receive them. The latest estimate from the World Bank puts their magnitude at roughly $\$ 283$

billion in 2008, and for many countries remittances are larger than the foreign official aid or private investments they receive. Some of the largest recipients of remittances are the Philippines, India, Pakistan, Brazil and Egypt. Mexico, for example, receives more than $\$ 26$ billion in remittances each year, primarily from migrants working in the U.S. Figure 1 shows remittance flows have been on the rise in the various regions for the period 1975 to 2004. As shown in Figure 2, a similar pattern holds

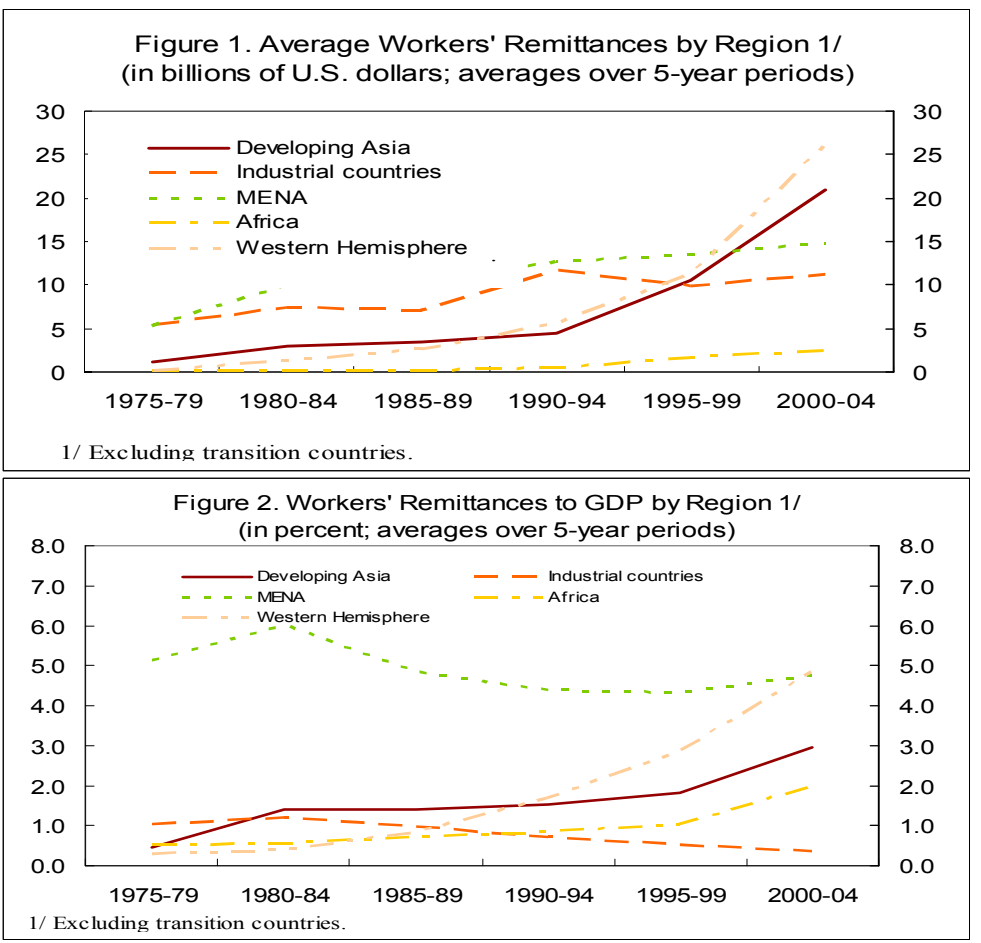


when remittance inflows are scaled by the size of the recipient economies. Interestingly, Figure 2 also shows that inflows of workers' remittances have been not only large, but also quite stable as a percent of GDP for most regions.

A number of papers have recently documented the economic and social effects of these flows. ${ }^{1}$ In particular, there is conclusive evidence that remittances directly alleviate poverty by providing significant income to some of the poorest members of society. This makes remittances very different from foreign aid or trade, which at best trickle down to the poor.

And remittances have been a remarkably stable source of income, relative to other private and public flows. Moreover, they seem to be compensatory in nature, rising when the home country's economy suffers a downturn. This countercyclical behavior of remittances has led some to believe that these flows are a tremendous stabilizing factor in many developing nations, at least, until now. That remittances may help stabilize output volatility in regions heavily dependent on these flows can be seen in Figure 3. For example, the potential for remittance inflows to stabilize GDP growth is of particular importance for developing countries in the MENA region, because these countries have traditionally been second only to African countries in growth instability as measured by the standard deviation of GDP growth rates.

This paper is an empirical investigation into the effect of remittances on output stability. That is, we attempt to answer the question whether remittance flows reduce output growth volatility in remittance-dependent economies. The issue of whether large remittance inflows in a developing country tend on average to be stabilizing or otherwise is an important one, since recent research has highlighted the adverse effect of high output volatility on economic growth, welfare, and poverty, particularly in the context of developing countries (Ramey and Ramey, 1995). It is therefore important to understand the implications of remittances for the volatility of output growth, and, in particular, whether the size of remittances is an important determinant of growth volatility.

We employ cross-section OLS and instrumental variables and Generalized Method of Moments (GMM) dynamic panel regressions to explain the standard deviation of real per capita GDP growth for a sample of 70 countries, including 16 advanced economies and 54 developing countries. Our objective is to determine whether the ratio of remittance receipts to GDP helps to explain the volatility of growth in these economies after controlling for a large number of variables that have been cited in the literature as potential determinants of such volatility. We find a robust, statistically significant negative effect of remittance flows on the

\footnotetext{
${ }^{1}$ See, for example, Chami and others (2003, 2008), IMF (2005), and WB (2006).
} 
volatility of real GDP growth: in other words, remittance inflows have tended to be stabilizing on average. We believe this an important finding, since, if as suspected, remittance flows are expected to slow down due to the ongoing global economic turmoil, then we should expect the most vulnerable and remittance-dependent economies to be significantly affected by the drop in these income flows.

The structure of the paper is as follows: to isolate the effect of remittance inflows on growth volatility, it is important to properly control for other potential determinants of growth volatility. Accordingly, Section II provides an overview of the literature on the determinants of growth volatility that is intended to identify the appropriate set of controls. Our first estimates, based on cross-section OLS regressions, are presented in Section III. To handle the potential endogeneity of remittance flows, Sections IV and V turn to instrumental variables and GMM estimations respectively. In Section VI, we consider the possibility that the effects of remittance flows on the stability of GDP growth may be nonlinear. A final section summarizes and concludes. The paper also contains a data appendix describing sources for the data used in the estimations as well as variable definitions.

\section{Determinants OF Growth Volatility}

A stylized fact of cross-country growth performance is that growth rates are not very persistent (Easterly, Kremer, and Summers 1993). This volatility in growth rates is important not only for its direct welfare effects, but also because it may affect the average growth rate itself, as documented by Ramey and Ramey (1995). Consequently, there is a growing literature attempting to explain growth volatility, which we briefly review in this section. The explanations that have been adduced to date tend to emphasize factors of three types: exogenous shocks, persistent characteristics of the domestic economic and policy environment that are responsible for generating or amplifying shocks, and deeper institutional factors making for social, political, and economic instability. We review each of these in succession, and conclude the section with a brief description of the effects of remittance flows on volatility that have been identified in the literature to date.

\section{A. Exogenous Shocks}

Easterly, Kremer, and Summers (1993) note that the lack of persistence in growth rates in the face of substantial persistence in the types of explanatory variables typically included in cross-country growth regressions suggests an important role for low-persistence shocks in determining growth rates. Empirically, they indeed find that much of the growth volatility they observe across countries at 10-year horizons (i.e., from one decade to the next) can be explained by low-persistence shocks and the domestic policy responses to them.

Specifically, they find that changes in decade-average growth rates are highly correlated with changes in the terms of trade, with variations in civil strife (measured by war casualties on domestic soil), with vulnerability to debt crises, and with changes in inflows of external transfers as a share of GDP. Shock variables of this type are found to add substantial explanatory power to simple growth regressions during both 1970s and 1980s. These results have been confirmed with more recent data by Calderon, Loayza, and Schmidt-Hebbel (2005). Using a sample of 76 countries over the period 1960-2000, they find that growth 
volatility is significantly affected by low-persistence external shocks. These include shocks to the terms of trade, to resource inflows, and to partner-country growth.

\section{B. Persistent Country Characteristics}

Subsequent work has focused on the roles of more persistent economic characteristics on volatility. Such characteristics include country size, income per capita, openness to trade, share of government consumption in GDP, degree of financial development, and degree of integration with world capital markets.

Furceri and Karras (2007) argue that country size matters because larger economies tend to have a more diversified structure of production, and thus are less vulnerable to sector-specific shocks. Their diversified production structure should therefore make larger countries more stable. Their empirical work supports this conjecture.

The sectoral composition of domestic production may also be affected by a country's level of development. Koren and Tenreyro (2004) argue that changes in income per capita are associated with patterns of sectoral specialization that have implications for macroeconomic volatility. Specifically, they find that as countries grow, they tend to concentrate production in less risky sectors. The degree of sectoral concentration in production also appears to decline initially with development, before flattening out and eventually reversing very gradually. Higher levels of income are also associated with reduced levels of country-specific risk, holding constant the structure of production. The upshot is that poor countries are more volatile because they have a less diversified production structure, because they specialize in more volatile types of production, and because they have other income-related characteristics that are associated with increased levels of domestic macroeconomic risk.

The role of trade openness has proven to be more controversial. For example, Rodrik (1998) notes that increased trade openness tends to be associated with a larger share of government consumption in GDP across countries, and explains this correlation as the outcome of a social mechanism to cope with macroeconomic risk: he argues that increased openness is associated with higher macroeconomic volatility, especially when exports are highly concentrated and the prices of export goods are themselves volatile. Thus, it is not just the variability of international commodity prices that matters, or how large a weight specific commodities carry in the country's export basket, but also how large exports are relative to the size of the economy. The latter two factors are persistent characteristics of the domestic economy that determine its vulnerability to fluctuations in commodity prices.

Rodrik argues further that a large share of government consumption in GDP reduces risk, because the government sector is a "safe" sector in the sense that the level of government employment as well as of government purchases from the rest of the economy are relatively stable. More open economies can therefore achieve enhanced income stability by increasing the share of government consumption in GDP.

Rodrik's perspective thus suggests that increased trade openness, a larger share of exports devoted to primary commodities, and more volatile terms of trade should all be associated 
with increased macroeconomic volatility, while a larger share of government consumption in GDP should be associated with reduced volatility.

However, both components of Rodrik's hypothesis have been disputed by others. In contrast to Rodrik (1998), Easterly, Islam, and Stiglitz (2000) note that the effect of trade openness on volatility may actually be ambiguous ex ante, since theory suggests that, while enhanced trade openness may leave a country more exposed to external shocks (as noted by Rodrik), it may be stabilizing in the face of domestic shocks. Moreover, government consumption has been shown to be procyclical in many low-income countries (Talvi and Vegh, Montiel and Serven 2005), which suggests that a larger share of government consumption in GDP may actually enhance rather than reduce macroeconomic volatility in such countries. Accordingly, the effect of the share of government consumption in GDP on growth volatility may depend on a country's income level.

Several authors have considered the role of domestic financial development as a determinant of volatility. Both Easterly, Islam, and Stiglitz (2000) as well as Cecchetti, Lagunes, and Krause (2005) find that domestic financial sector development tends to reduce volatility. These studies provide empirical support for this proposition after controlling for the effect of commercial openness (though Easterly, Islam, and Stiglitz conclude that the effect of financial development may be nonlinear, weakening at higher levels of financial development). This emphasis on the stabilizing effects of financial development for middle-income countries is consistent with Caballero's (2000) finding that macroeconomic volatility in Latin America has been driven by two main factors: a low state of domestic financial development and weak links with international financial markets.

While Caballero (2000) considers that weak financial integration enhances volatility in Latin America, other authors have reached exactly the opposite conclusion. As in the case of trade openness, it is acknowledged that financial openness introduces vulnerability to fluctuations in external economic conditions, which in this case refers to external financial conditions in the form of exogenous changes in the world risk-free interest rates, in country risk premia, or in capital inflows. The question is whether financial openness may compensate for this new source of volatility by stabilizing domestic production in the face of purely domestic shocks (as suggested in the case of commercial openness), or whether it actually aggravates the effects of such shocks. The standard textbook analysis suggests that financial openness is stabilizing when domestic shocks are real in origin and the country maintains a floating exchange rate, or when domestic shocks are monetary in origin and the exchange rate is fixed. A more sophisticated story is that financial openness may even reduce the incidence of domestic shocks, by disciplining domestic policymakers. However, those who argue that financial openness is destabilizing emphasize two characteristics of capital flows that tend to be destabilizing: they tend to be procyclical (Stiglitz 2000), and international capital markets may often respond in a disproportionate manner to domestic shocks, as noted in the "sudden stop" literature.

The evidence is mixed. As already mentioned, both Easterly, Kremer, and Summers (1993), as well as Calderon, Loayza, and Schmidt-Hebbel (2005), find that volatility in resource inflows contribute to growth volatility. Clearly, such shocks would not affect the domestic 
economy under financial autarky. However, restricting attention to the role of external financial volatility misses the potential stabilizing role that financial integration can play by ameliorating the effects of domestic shocks. A more appropriate test is to examine the effects on growth volatility of financial integration itself, rather than of exogenous financial shocks. Calderon, Loayza, and Schmidt-Hebbel (2005) conduct such an exercise, finding that the effects of financial integration on growth volatility are generally negative (i.e., increased financial integration tends to be stabilizing) except perhaps at intermediate income levels. ${ }^{2}$ They also find that financial openness tends to reduce the volatility effects of several types of exogenous shocks.

\section{The Institutional Environment}

While budgetary institutions and financial sector development are two aspects of the domestic institutional environment that may affect macroeconomic volatility, several authors have emphasized that deeper aspects of the domestic institutional environment may be even more important in affecting volatility. Rodrik (1998) for example, points to the quality of domestic institutions of internal conflict management. These affect macroeconomic volatility through the country's response to external shocks. Such shocks often give rise to social conflict, and in countries with poor institutions of domestic conflict management, the result may be a growth collapse. This analysis points to indices of ethnic fragmentation, of democratic rights, and of the quality of government institutions, as potential "deep" empirical determinants of macroeconomic volatility. Rodrik's results are supported by Mobarak (2005), who finds that democracy, high levels of income per capita, trade openness, and various measures of economic diversification, are all associated with reduced macroeconomic volatility.

In Rodrik's framework, a poor domestic institutional framework generates volatility by magnifying the economic dislocations associated with exogenous shocks. Acemoglu and others (2003) go even further in linking volatility to the quality of the domestic institutional environment. They argue that an institutional environment that places only weak constraints on politicians and political elites itself generates volatility, even in the absence of exogenous shocks. There is a variety of mechanisms that could generate this effect. For example, in the absence of such constraints, a turnover of power from one group to another is likely to imply the implementation of redistributive policies, which can be expected to destabilize aggregate economic performance. Moreover, since the opportunity to implement such policies implies that the group that obtains political power can make large economic gains for itself by doing so, jockeying for political power is likely to be intense under these circumstances, generating social conflict that manifests itself in macroeconomic instability.

\footnotetext{
${ }^{2}$ They find a positive effect on volatility at intermediate income levels using their policy measure of integration, but not their outcome measure.
} 


\section{Remittance Flows}

How do remittance flows fit into all this? The theoretical effects of remittance inflows on macroeconomic volatility are ambiguous in principle. The presence of remittance flows represents an additional dimension of macroeconomic openness, and to the extent that remittance flows are both exogenous and volatile, they would tend to induce volatility to the recipient economy much like volatility in the terms of trade or in capital flows. However, the evidence suggests that remittances are both relatively stable, compared to other types of external flows, and that they behave countercyclically (see Chami and others, 2003, 2008, and references therein). This being so, conditional on the quality of the domestic institutional environment, we would expect remittance flows to be macroeconomically stabilizing, in the same sense that countercyclical fiscal policy would be.

However, there are two caveats to this argument. First, to the extent that fluctuations in growth are driven by labor-supply responses to technology shocks, countercyclical remittance flows may actually tend to amplify those responses - for example, if a positive technology shock elicits an increase in labor supply because the real wage is temporarily high, and if remittance flows contract in response to the resulting increase in domestic income, the negative income effect associated with the contraction in remittances may reduce household demand for leisure, thereby magnifying the increase in the supply of labor. Thus, if income effects on the supply of labor are large and remittances are countercyclical, their presence may magnify volatility in GDP growth (see Chami, Cosimano, and Gapen, 2006).

Remittance flows may also affect volatility through effects on the quality of domestic institutions. The presence of remittance flows may enhance financial development in the recipient country, a factor which, as mentioned above, has been found to be stabilizing. On the other hand, at a more fundamental level, the availability of remittance income may undermine the quality of other domestic economic institutions. There is evidence, for example, that reliance on remittance flows may have an adverse effect on the quality of governance in the recipient countries (Abdih and others, 2008). If so, the recipient economy may be more susceptible to being destabilized by economic shocks, whether domestic or external in origin.

There is little evidence to date on the effects of remittance flows on volatility. However, IMF (2005) found that an increase in the share of remittance flows in GDP is associated with a significant (statistically and economically) reduction in volatility of GDP growth, suggesting that the stabilizing influence of countercyclical remittance flows on aggregate demand - and possibly the effects of such flows on domestic financial development - may outweigh the supply-side and institutional effects of remittances.

\section{Ordinary Least Squares Estimation}

This section reports the results of cross-section OLS regressions explaining the standard deviation of real per capita GDP growth over the 1970-2004 period for a sample of 70 countries, including 16 advanced economies and 54 developing countries. Our concern is with the role of the ratio of workers remittances to GDP in these regressions, but to avoid 
omitted variable bias we control for a large number of variables that have been used in other studies examining output volatility, as described in the previous section. Our control variables include relative income, relative income squared, terms of trade volatility, trade openness, financial openness, government consumption, institutional quality, an indicator of financial sector development, a trade concentration ratio, and an indicator of the commodity composition of exports (Data Appendix contains data sources and variable definitions).

The explanatory variables are constructed as averages over the 1970-2004 period except for the relative income variable, which is measured by its value in 1970 . We require that at least fifteen years of data are available to calculate the average of a variable. Also, the average of a variable is calculated including only those years for which the data are not missing for all the explanatory variables included in the regression. Table 1 reports output volatility and the average ratio of workers remittances to GDP over the 1970-2004 period for each country in the sample. The average remittances flow into the 70 countries in the 1970-2004 sample is 1.7 percent of GDP compared with a median remittances flow of 0.4 percent of GDP. The three largest recipients of remittances relative to GDP over the 1970-2004 period were, in order, Jordan (19 percent of GDP), Egypt (8.2 percent of GDP), and El Salvador (7 percent of GDP). The data show that some industrial countries also received substantial remittances (Portugal, 5.7 percent of GDP, Greece, 2.1 percent of GDP, Cyprus, 0.6 percent of GDP, and Spain, 0.5 percent of GDP). The average volatility of per capita output growth is 4.4 percent for the 1980-2004 period and compares with a median of 3.6 percent. Table 2 provides descriptive statistics for all the explanatory variables included in the regressions.

As a first step, we estimate an OLS regression that includes all the possible explanatory variables in the regression. The preferred specification is obtained after dropping insignificant variables and restricting the countries included in the regression sample to be the same as for the regression that includes all of the explanatory variables. The results are reported in Table 3. The first two columns of the table report the general results with all countries and all control variables included. Column 2 differs from column 1 in that the former includes an interaction term between government consumption and an industrialcountry dummy, to allow for the possibility that procyclicality in government spending in developing countries may cause the effect of the size of the government sector on macroeconomic volatility to differ in the two types of countries. As indicated in columns 1 and 2, the key control variables appear to be those related to the country's external trade that is, the share of primary commodities in exports, degree of trade openness, and terms of trade volatility. The point estimate of the coefficient on the ratio of worker remittances to GDP is negative in both cases, and is statistically significant at the 95 percent level when the effects of the share of government consumption in GDP are allowed to differ between industrial and developing countries (column 2).

Column 3 drops all insignificant control variables except the government consumption variables from the regression and is our preferred OLS specification. Among the control variables, only the trade and fiscal variables provide significant explanatory power. The key 
result, however, is that the effect of workers' remittances continues to be negative and statistically significant. Thus, a higher ratio of remittances to GDP tends to reduce the volatility of real GDP growth, after controlling for other statistically significant determinants of growth volatility.

As shown in column 4, this result is unchanged when the sample is restricted to developing countries, with the magnitude of the coefficient on the remittance variable essentially identical to that for the full sample. Indeed, the stabilizing effects of remittance flows may actually be somewhat stronger than these results would suggest, because the estimated coefficient of the remittance ratio is significantly affected by a single outlier. Specifically, Jordan is by far the largest remittance recipient in the sample, but also happens to be characterized by substantial volatility in GDP growth during the sample period. Omitting Jordan from the sample, as in column 5, significantly increases the absolute value of the remittance ratio in the full sample.

The upshot is that the results of the cross-country OLS regressions indicate that there is a negative relationship between workers' remittances and the volatility of output growth, and that this relationship is statistically significant. In practical terms, an increase in the workers' remittances-to-GDP ratio of one percentage point leads to a reduction of 0.16 in the standard deviation of GDP growth, according to the preferred regression results including Jordan.

Recent research has highlighted an important effect of higher volatility in discretionary fiscal spending - measured as the standard deviation of cyclically adjusted government spending-for increasing output volatility (see Fatás and Mihov 2003, and Hakura, 2007). In fact, including a variable capturing discretionary fiscal policy volatility tends to weaken the effect of many of the explanatory variables, but the findings on the remittance variable are robust to the inclusion of the fiscal volatility variable (columns 6 and 7). ${ }^{3}$

\section{INSTRUMENTAL VARIABLES ESTIMATION}

This section reports the results of an instrumental variables (IV) analysis that corrects for potential endogeneity of the remittances variable. If remittances are motivated by altruism-a desire by migrants to compensate family when they encounter bad times, including an uncertain economic environment-remittance inflows may increase in response to increased macroeconomic volatility in the recipient country. In this case, estimates of the effect of remittances on output volatility derived from OLS estimation may be biased upwards (making them less negative or more positive than the underlying true parameter). If this bias is present, therefore, the stabilizing effects of remittance flows may actually be understated by the results of the last section.

The IV estimations here cover the same countries, estimation period and equation specification as the OLS estimations in the previous section. Two key features govern the

\footnotetext{
${ }^{3}$ Jordan is excluded in these regressions because of lack of data.
} 
selection of an instrument for remittances: the instrument must be correlated with remittances, and its effect on individual country output growth volatility must operate solely through its effect on remittances and should not be directly affected by output volatility in individual countries. ${ }^{4}$ The instrument that is used here is the ratio of remittances to GDP of all other recipient countries $\left(\right.$ wrrow $\left._{i}\right){ }^{5}$ This variable captures various trends in remittances throughout the world, including changes in transactions costs and at the same time should not directly affect output volatility in individual countries. The instrument excludes the remittance-to-GDP ratio of the country in question thereby freeing it of a direct causal link with other domestic macroeconomic and policy variables that also influence output volatility.

The first stage regression is given by

$$
w r_{i t}=\alpha_{i}+\beta \text { wrrow }_{i t}+u_{i t}
$$

where $w r_{i t}$ denotes the ratio of workers' remittances to GDP in country $i$ and year $\mathrm{t}$, and wrrow $_{i t}$ denotes the ratio of workers' remittances to GDP in the rest of the world - that is, in all countries except $i$ - in year $t$. Thus, the first stage regression includes the general world trend in remittances as an explanatory variable, along with a country-specific fixed effect to determine the average level of remittances for each given country. The second stage includes the average over the 1980-2004 period of the fitted values from the first stage as a regressor.

Column 8 of Table 3 shows the results of the instrumental variables estimation using the fitted $w r$ as the relevant explanatory variable. The IV regressions confirm the OLS regressions. The IV estimates suggest a significant, negative impact of remittances on output volatility. The magnitude of the estimated impact is slightly larger in absolute value in the IV regression than in the OLS regressions consistent with the prevalence of some endogeneity.

\section{Generalized Method of Moments Dynamic Panel Estimation}

A dynamic panel method has several advantages over OLS as a statistical approach to examining the relationship between remittances and output volatility. First, estimation using panel data - that is, pooled cross-section and time series data-allows one to exploit the time series nature of the relationship between remittances and output volatility. Since the magnitude of remittance flows has changed substantially over time, this is an important advantage. Second, the dynamic panel estimator controls for the potential endogeneity of the

\footnotetext{
${ }^{4}$ Hakura (2007) shows that output volatility in developing countries is mostly explained by country-specific effects. Therefore, a downturn in one developing country which could trigger higher remittances is not highly correlated with high output volatility in all other low-income countries which would trigger higher total remittances.

${ }^{5}$ See Chami and others (2008) for a discussion of the instrument.

${ }^{6}$ Using the initial or lagged values of remittances to GDP would also have been a simple way to address the issue of endogeneity instead of instrumenting for contemporaneous values of remittances to GDP. However, this approach is ruled out by the paucity of the early data on remittances.
} 
remittance variable as well as the other explanatory variables. The GMM regression specifications reported in the paper control for the endogeniety of the remittances-to-GDP and the trade openness variables (in line with previous studies that have included trade openness, e.g., Calderon, Normal, and Schmidt-Hebbel, 2005). The results reported here are robust to controlling only for endogeneity of the remittances-to-GDP ratio.

The paper uses the GMM estimator developed by Arrellano and Bond (1991) for dynamic panel data. For that purpose, the data is organized into a panel consisting of 70 countries over the 1980-2004 period (the 1970s data are dropped in the panel estimations because the remittance data are missing for many countries during those years). The data are averaged over non-overlapping five-year periods so that - data permitting - there are five observations per country (1980-1984, 1985-1989, 1990-1994, 1995-1999, and 2000-2004). Table 4 provides a description of the data.

The regression is specified as follows:

$$
v_{i, t}=\beta^{\prime} X_{i, t}+\eta_{i}+\varepsilon_{i, t}
$$

where $v_{i, t}$ is the volatility of output growth, measured as the standard deviation of the growth rate over the relevant five-year period; $X$ represents the set of explanatory variables discussed previously; $\eta_{i}$ is an unobserved country-specific effect; $\varepsilon$ is a time- and country-specific error term; and the subscripts $i$ and t represent country and time period, respectively. Time period dummies are also included to capture period-specific effects.

The standard assumptions that (i) the error term is not serially correlated; and (ii) the explanatory variables are weakly exogenous (i.e., they are uncorrelated with future realizations of the error term), yield the following moment conditions:

$$
E\left[X_{i, t-s} \cdot\left(\varepsilon_{i, t}-\varepsilon_{i, t-1}\right)\right]=0 \quad \text { where } i=1, \ldots, N, t=3, \ldots, T \text { and } s \geq 2
$$

This condition allows the use of suitably lagged levels of the variables as instruments, after the equation has been first-differenced to eliminate the country-specific effects. The explanatory variables are the same as in the case of the OLS cross-section regression estimation of the last section, with the exception of the indicator of the commodity composition of exports, which is fixed for each country over time and, therefore drops out in the first differenced equations.

It is worth noting that, while the GMM difference estimator has important advantages for our purposes, it is also subject to some important shortcomings. Specifically, the difference estimator has been found to have poor finite sample properties (bias and imprecision) when 
the lagged levels of the series are only weakly correlated with subsequent first differences, and therefore make weak instruments. This has been found to be the case when the explanatory variables are highly persistent or close to a random walk. To reduce the potential biases and imprecision associated with the difference GMM estimator, an extended GMM estimator is used that combines in a system the regression in differences with one in levels (see Blundell and Bond, 1998). The instruments for the regressions in differences are suitably lagged levels of the series, as described above. The instruments for the regressions in levels are in turn suitably lagged first differences of the variables. These are appropriate instruments assuming that $E\left[\Delta x_{i, t} \eta_{i}\right]=0$, which yields the additional moment conditions:

$$
E\left[\Delta x_{i, t-s}\left(\eta_{i}+\varepsilon_{i . t}\right)\right]=0 \text { for } s=1 .
$$

The consistency of the GMM estimator depends on the validity of the instruments. We test the validity of the instruments using three specification tests. The first is the standard Sargan test of overidentifying restrictions, which tests the overall validity of the instruments by analyzing the sample analog of the moment conditions used in the estimation process. The second test, the difference Sargan test, examines the validity of the additional moment conditions imposed in the levels equations by the system GMM estimator. The third test examines the hypothesis that there is no second-order serial correlation in the first-differenced residuals.

The system panel results are reported in Table 5. The table reports five sets of estimates. In the first column, we present OLS panel estimates for the full sample. The signs of the parameter estimates are the same as those in the cross-section regressions. Most importantly, the coefficient on the remittance ratio remains negative, though it is not significant at standard levels in this case. The second column presents within-group estimates, which eliminate cross-sectional variation by introducing country fixed effects. These estimates yield similar results, except that the control variable capturing trade openness now becomes significant. Columns 3 - 5 report the GMM system estimates, with columns 3 including the full sample, column 4 excluding Jordan and column 5 reporting results only for developing countries. These results confirm the findings from the cross-section OLS and IV regressions. The remittances variable is negative and statistically significant in all three of these regressions. The magnitude of the effect of remittances on volatility is very similar across these three regressions, and the pattern of coefficients on the control variables is similar as well. Thus, the full-sample GMM results are robust to dropping industrial countries from the sample and excluding Jordan. However, while the coefficient on the remittance variable is very similar across the three samples used in the GMM regressions, it is much larger in absolute value in the GMM regressions than in the OLS and within-group regressions.

The panel GMM system estimates pass the specification tests. The Hansen test and the Difference Sargan tests, which focus on the additional instruments used by the system, do not reject the validity of the instruments. The additional instruments in the system GMM 
therefore seem to be valid and highly informative. The serial correlation tests also do not reject the econometric model due to serial correlation.

\section{TESTING FOR NONLINEAR EFFECTS}

There is some evidence that the macroeconomic effects of worker remittances in the recipient economies may depend on the size of remittance flows - that is, the effects of the remittance variable may be nonlinear (see Abdih and others, 2008, Chami and others, 2006 and 2008). If this nonlinearity extends to the effects of remittance inflows on the volatility of GDP growth, the results of the previous section may disguise some heterogeneity in the stabilizing effects of remittance inflows. Chami and others (2006, 2008), using a stochastic dynamic general equilibrium model with endogenous labor supply, show that at a high level of remittance-toGDP ratio may actually enhance output volatility due to the negative impact of these flows on the labor supply of remittance-dependent households. Abdih and others, 2008, show that high levels of remittance-to-GDP may actually lead to higher levels of corruption. One possible explanation could be that countries that over a long sample period had high remittances have felt less need for reforms and thus have left the economy with a narrow base prone to exogenous shocks.

To test for the existence of a nonlinear effect of remittances on growth volatility using the OLS, IV, and GMM system estimators, the workers remittance variable is interacted with a dummy variable that takes the value of 1 for remittance ratios greater than $r *$ percent and zero otherwise, and this interaction term is included as an additional explanatory variable in the regressions reported earlier. Remittance cutoffs from 0.5 to 0.5 percent below the maximum value of the remittance ratio to GDP in the sample (the highest feasible cutoff) are explored, by increments of 0.5 percent. The test for no nonlinear effect amounts simply to the test of the null hypothesis that the coefficient on the interactive variable is equal to zero. Under OLS and IV, the optimal cutoff is the one that minimizes the residual sum of squares. Under the GMM dynamic system estimator, the optimal cutoff is the one that minimizes the Hansen test statistic when the same instrument set is used in all the equations. The tests for the optimal cutoff instrument the interactive remittance variable using lagged levels and lagged differences of the square of the remittances to GDP ratio in the differenced and level regressions respectively. Once the optimal cutoff is selected, the instruments of the interactive remittance variable are allowed to be the lagged level and differences of the variable itself.

The OLS and IV results are reported in Table 6, for the full sample and excluding Jordan. The optimal cutoff value for the remittance variable that minimized the sum of squared residuals in the regression proved to be 2 percent of GDP. Using this cutoff value generated results that were very similar to those derived previously. Again, all of the control variables have the expected sign and the signs of the coefficients on both remittance variables (above and below the cutoff value) are negative and significant at the one percent level. The 
intriguing result is that the effect of remittance inflows on growth volatility indeed appears to be highly nonlinear: in countries where remittance inflows exceed 2 percent of GDP an additional percentage point of GDP of remittance inflows has a much weaker moderating effect on growth volatility than in countries that receive inflows of less than 2 percent of GDP. Thus remittance inflows are stabilizing on average for all recipients, but the stabilizing effects of remittance inflows appear to be achieved rather quickly (i.e., at relatively low remittance-to-GDP ratios) and to weaken when inflows are very large.

IV regression results carried out to correct for endogeneity problems mirror the OLS findings. The stabilizing effect of an additional percentage point of remittance inflows in countries that receive inflows below 2 percent of GDP is estimated to be slightly less than in the OLS estimations. The GMM estimates are reported in Table 7-once again for panels with the full sample, excluding Jordan, and only including developing countries. The nonlinear effect appears to be even stronger in the GMM estimates than in the OLS and IV estimations. The stabilizing effects of an additional percentage point of remittance inflows on the volatility of GDP growth appear to be almost a full order of magnitude smaller in countries that receive inflows in excess of 2 percent of GDP than in countries with inflows below 2 percent of GDP.

\section{An Application: Remittances and OUtPut Stability in the Middle East and NORTH AFRICA}

The nonlinearity in the effects of remittances on growth volatility may play an important role in interpreting the welfare effects of remittance flows in specific context. As an example, this section considers the contribution of remittance receipts to macroeconomic stability in countries in the Middle East and North African region (MENA).

As stated earlier, for the period 1975-2004 remittance flows into MENA countries have been large, stable, and may have contributed to output stability (see Figures 1-3). However, this is where the nonlinearity in the effects of remittances on growth stability becomes important. Because the level of remittance inflows exceeded 2 percent of GDP throughout the period, we estimate that the contribution of such inflows to lower volatility has in fact been lower for countries in the MENA region than for developing countries elsewhere over much of the 1975-2000 period (Table 8). Other regions (Developing Asia and Western Hemisphere) are only now starting to have remittances that exceed 2 percent of GDP, suggesting that the volatility-reducing effects of remittances in these regions may also be declining.

Nonetheless, impacts on volatility can remain important when changes in remittance flows are large, even when countries are already large inflow recipients. For example, many MENA countries receive a large amount of their remittance inflows from GCC oil exporting countries. Consequently, periods with high oil prices have been associated with substantial increases in remittance flows to these countries, and the most recent period of high oil prices has been no exception. Remittances have increased in MENA countries such as Pakistan 
(from 2 percent of GDP in 2001 to 4 percent of GDP in 2006) and Egypt (from 3 percent of GDP in 2001 to 5 percent of GDP in 2006) by about 2 percent of GDP over the last five years. Applying the relevant coefficient estimate from Table 7, suggests that the increase in remittance may have contributed to a reduction in growth volatility by about 0.4 percent for these countries respectively in these years.

\section{SUMMARY AND CONCLUSIONS}

We have provided evidence that remittance flows have indeed contributed on average to reducing the volatility of GDP growth in remittance-receiving countries, even after controlling for a large number of other potential determinants of growth volatility and taking into account the possible effect that growth volatility may itself exert on remittance flows. This provides an important channel through which remittance inflows may affect both growth and welfare in remittance-receiving countries.

However, the evidence on the existence of threshold effects suggests that the stabilityenhancing effects of remittances appear to be achieved rather quickly, so whatever benefits may be associated with very large remittance flows, enhanced macroeconomic stability may not loom large among them. This emphasizes the importance of strengthening macroeconomic resilience through other means in countries that are very large recipients of remittances. Fortunately, remittance resources may themselves provide the means to do so, including possibly through broad-based taxation of consumption, increases in which have been financed in many countries from the remittance inflows. An efficient VAT with limited exemptions could net for the domestic government a substantial share of the resources received through remittance inflows by countries that are large remittance recipients. These resources could be used to boost the human capital of the domestic population by improving health and education services, to alleviate infrastructure bottlenecks, and to improve the business climate so as to maximize the spillover effects of remittance inflows to the broader economy.

Finally, in light of the preponderance of evidence that the current global economic turmoil may lead to a significant drop in remittance flows to developing and emerging economies, the question arises as to what could be the implication for the remittance-recipient economies. Moreover, what could governments in those countries do to mitigate the social and financial impact of such a drop in these flows? The evidence on the positive impact of remittance flows on output stability presented in this paper suggests that the slow down or drop in remittance flows are likely to increase the volatility of the output, which is likely to have adverse welfare effects in the remittance-recipient countries. First, the loss of income from remittances is likely to hit the poorest the hardest, as these flows are typically used to purchase consumption goods as well as to complement limited public social insurance. Second, with migrants losing their jobs in the host countries and returning home, this is likely to raise unemployment in the home country.

Governments in the affected countries - who may have relied on these flows to reduce poverty, provide insurance against consumption shocks to households, and to increase the tax revenue by raising the consumption of goods and services purchased by these households- 
may now see these benefits evaporate. Unemployment pressures due to returning migrants, and the urgency to replace the remittance-funded insurance to recipient households will place pressure on these governments to look into their limited policy tool box to find ways to alleviate the economic and social pressures arising from the loss of these benefits. One possibility is for governments in remittance-dependent countries to step up their fiscal expenditures on social insurance. This, however, will not be an easy task, since some of these countries will be impacted by the slow down in the global demand for their exports, which is likely to depress government revenue and limit borrowing capacity. Also, fiscal expenditures and employment-generating initiatives undertaken by governments in remittance-sending countries could also help in this context, to the extent that these measures may lower the possibility of more migrants losing their jobs and then having to decrease their remittances or having to return to their home countries. 
Table 1: Output Volatility and Workers Remittances

\begin{tabular}{|c|c|c|c|c|c|}
\hline Country & $\begin{array}{c}\text { Output volatilit } \\
\text { (std. deviation } \\
\text { of per capita } \\
\text { output growth, } \\
\text { 1970-2004) }\end{array}$ & $\begin{array}{l}\text { y Workers } \\
\text { remittances to GDP, } \\
\text { averages 1970-2004 }\end{array}$ & Country & $\begin{array}{c}\text { Output volatility } \\
\text { (std. deviation } \\
\text { of per capita } \\
\text { output growth, } \\
\text { 1970-2004) }\end{array}$ & $\begin{array}{l}\text { Workers } \\
\text { remittances to GDP, } \\
\text { average } 1970-2004\end{array}$ \\
\hline Chile & 6.7 & 0 & Niger & 7.2 & 0.4 \\
\hline Denmark & 2.2 & 0 & Spain & 1.7 & 0.5 \\
\hline Finland & 3.5 & 0 & Paraguay & 3.5 & 0.5 \\
\hline Iran & 8.7 & 0 & New Zealand & 2.3 & 0.5 \\
\hline Kenya & 3.1 & 0 & Cyprus & 5.2 & 0.6 \\
\hline Malaysia & 2.8 & 0 & Colombia & 1.9 & 0.9 \\
\hline Papua New Guinea & 14.5 & 0 & Peru & 5.8 & 1.0 \\
\hline Syria & 6.9 & 0 & Mexico & 3.6 & 1.0 \\
\hline United States & 2.8 & 0 & Uganda & 4.7 & 1.2 \\
\hline Venezuela & 5.6 & 0 & Philippines & 4.2 & 1.3 \\
\hline Cote d'Ivoire & 6.1 & 0 & Nigeria & 6.1 & 1.4 \\
\hline Japan & 2.0 & 0.004 & Malta & 5.5 & 1.5 \\
\hline Ireland & 3.3 & 0.01 & India & 2.2 & 1.5 \\
\hline Thailand & 3.1 & 0.01 & Togo & 5.3 & 1.6 \\
\hline Norway & 1.9 & 0.01 & Guatemala & 2.2 & 1.6 \\
\hline Malawi & 6.7 & 0.02 & Ecuador & 3.4 & 1.8 \\
\hline Gabon & 7.1 & 0.02 & Greece & 2.5 & 2.1 \\
\hline Zimbabwe & 9.7 & 0.02 & Turkey & 4.1 & 2.1 \\
\hline Hungary & 3.6 & 0.02 & Senegal & 5.0 & 2.5 \\
\hline Sweden & 2.0 & 0.02 & Sudan & 4.4 & 2.7 \\
\hline Argentina & 6.4 & 0.04 & Honduras & 3.9 & 2.8 \\
\hline France & 1.4 & 0.1 & Mali & 5.6 & 3.9 \\
\hline Republic of Korea & 4.3 & 0.1 & Tunisia & 1.5 & 4.2 \\
\hline Ethiopia & 10.3 & 0.1 & Dominican Republic & 3.5 & 4.7 \\
\hline Madagascar & 3.4 & 0.1 & Sri Lanka & 3.1 & 5.0 \\
\hline Cameroon & 7.4 & 0.1 & Nicaragua & 3.9 & 5.0 \\
\hline Austria & 2.0 & 0.2 & Pakistan & 2.0 & 5.0 \\
\hline Italy & 1.9 & 0.2 & Jamaica & 3.5 & 5.2 \\
\hline Ghana & 7.3 & 0.2 & Burkina Faso & 3.5 & 5.7 \\
\hline Panama & 4.7 & 0.2 & Portugal & 3.1 & 5.7 \\
\hline Trinidad \&Tobago & 9.2 & 0.3 & Morocco & 4.8 & 6.6 \\
\hline Belgium & 1.7 & 0.3 & El Salvador & 2.9 & 7.0 \\
\hline Indonesia & 4.2 & 0.3 & Egypt & 2.7 & 8.2 \\
\hline Bolivia & 1.8 & 0.4 & Jordan & 6.8 & 19.0 \\
\hline Poland & 3.1 & 0.4 & & & \\
\hline \multirow[t]{2}{*}{ Costa Rica } & 3.5 & 0.4 & Average & 4.4 & 1.7 \\
\hline & & & Median & 3.6 & 0.4 \\
\hline
\end{tabular}


Table 2: Descriptive Statistics of Dependent and Explanatory Variables 1970 - 2004 (70 Observations)

\begin{tabular}{lcccc}
\hline Variable & $\begin{array}{c}\text { Mean } \\
\text { Maximum } \\
\text { Value }\end{array}$ & $\begin{array}{c}\text { Minimum } \\
\text { Value }\end{array}$ & $\begin{array}{c}\text { Standard } \\
\text { Deviation }\end{array}$ \\
\hline & & & & \\
Output Volatility (standard deviation of per capita GDP growth) & 4.4 & 14.5 & 1.4 & 2.4 \\
Workers remittances to GDP & 1.7 & 19.0 & 0 & 2.9 \\
Relative initial income (income relative to U.S. in 1970) & 0.3 & 1.0 & 0.03 & 0.3 \\
Relative initial income squared & 0.1 & 1.0 & 0.001 & 0.2 \\
Primary commodity export composition & 38.1 & 98.2 & 0.8 & 30.2 \\
Trade concentration ratio & 1.9 & 4.2 & 0.0 & 0.9 \\
Terms of trade volatility & 11.3 & 29.4 & 1.7 & 6.7 \\
Trade openness to GDP & 62.9 & 215.9 & 11.9 & 35.2 \\
Private credit to GDP & 0.4 & 1.5 & 0.03 & 0.3 \\
Bureaucracy quality & 6.7 & 12 & 0 & 3.1 \\
Financial openness (the stock of foreign assets and liabilities to GDP) 130.7 & 721.8 & 31.2 & 106.4 \\
Government consumption to GDP & 20.7 & 54.8 & 7.3 & 7.7 \\
Government consumption to GDP*industrial country dummy & 4.3 & 25.7 & 0.0 & 8.2 \\
& & & & \\
\hline
\end{tabular}


Table 3: Ordinary Least Squares and Instrumental Variables Regression Results Dependent Variable is: Volatility of Output Growth, 1970 - 2004

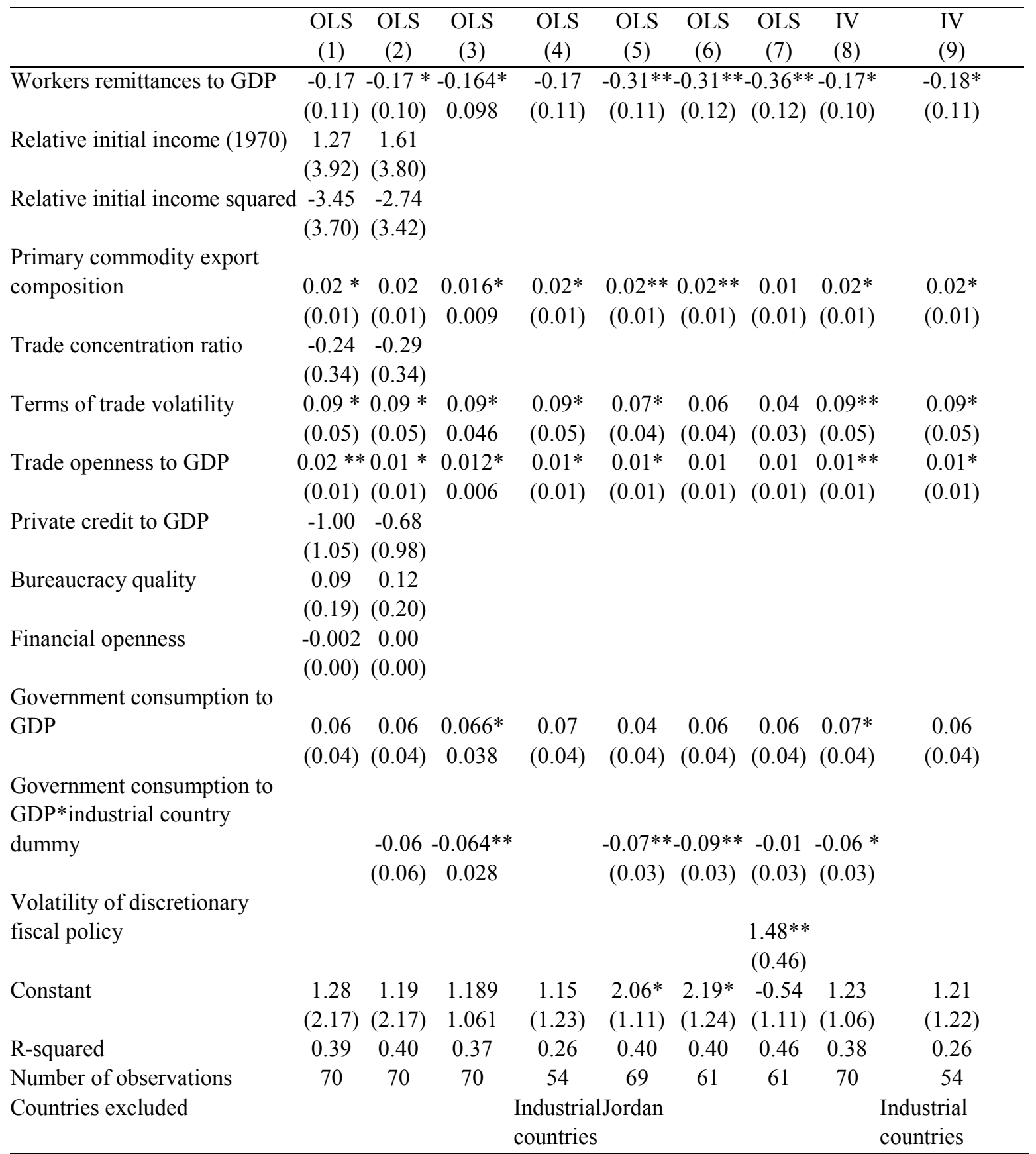

Notes:

Output growth volatility is the standard deviation of real GDP per capita growth over 1970-2004.

Robust standard errors are in parentheses.

See Data appendix for variable definitions.

A * denotes significance at the 10 percent level and ** denotes significance at the 5 percent level.

IV instruments the remittance to GDP ratio using the remittances to GDP ratio in the rest of the world (see text for explanation). 
Table 4: Panel Data Description, 1980 - 2004

(5-year period observations, 330 observations)

\begin{tabular}{lcccc}
\hline Variable & Mean & $\begin{array}{c}\text { Maximum } \\
\text { Value }\end{array}$ & $\begin{array}{c}\text { Minimum } \\
\text { Value }\end{array}$ & $\begin{array}{c}\text { Standard } \\
\text { Deviation }\end{array}$ \\
\hline Output Volatility (standard deviation of per capita GDP growth) & 3.4 & 18.7 & 0.3 & 2.7 \\
Workers remittances to GDP & 1.8 & 22.3 & 0.0 & 3.4 \\
Terms of trade volatility & 9.6 & 57.1 & 0.6 & 8.2 \\
Trade openness to GDP & 64.5 & 227.1 & 10.3 & 38.8 \\
Government consumption to GDP & 20.7 & 59.3 & 4.7 & 8.2 \\
Government consumption to GDP*industrial country dummy & 4.1 & 27.6 & 0.0 & 8.1 \\
& & & & \\
\hline
\end{tabular}


Table 5: Panel Regression Results

Dependent Variable is: Volatility of Output Growth, 1980 - 2004

(5-year period observations)

\begin{tabular}{|c|c|c|c|c|c|}
\hline & OLS Levels & Within Groups & GMM-SYS & GMM-SYS & GMM-SYS \\
\hline Workers remittances to GDP & $\begin{array}{l}-0.06 \\
(0.05)\end{array}$ & $\begin{array}{l}-0.08 \\
(0.06)\end{array}$ & $\begin{array}{c}-0.17 * * \\
(0.08)\end{array}$ & $\begin{array}{c}-0.19^{* *} \\
(0.07)\end{array}$ & $\begin{array}{c}-0.15^{*} \\
0.09\end{array}$ \\
\hline Terms of trade volatility & $\begin{array}{l}0.10 * * \\
(0.03)\end{array}$ & $\begin{array}{l}0.10 * * \\
(0.03)\end{array}$ & $\begin{array}{l}0.09 * * \\
(0.03)\end{array}$ & $\begin{array}{l}0.08 * * \\
(0.03)\end{array}$ & $\begin{array}{c}0.08 * * \\
0.03\end{array}$ \\
\hline Trade openness to GDP & $\begin{array}{c}0.00 \\
(0.00)\end{array}$ & $\begin{array}{l}0.02 * * \\
(0.01)\end{array}$ & $\begin{array}{c}0.01 \\
(0.01)\end{array}$ & $\begin{array}{c}0.01 \\
(0.01)\end{array}$ & $\begin{array}{l}0.00 \\
0.01\end{array}$ \\
\hline Government consumption to GDP & $\begin{array}{c}0.03 \\
(0.02)\end{array}$ & $\begin{array}{c}0.05 \\
(0.05)\end{array}$ & $\begin{array}{l}0.03^{*} \\
(0.02)\end{array}$ & $\begin{array}{c}0.02 \\
(0.02)\end{array}$ & $\begin{array}{l}0.03 \\
0.02\end{array}$ \\
\hline \multicolumn{6}{|l|}{ Government consumption to } \\
\hline GDP*industrial country dummy & $\begin{array}{c}-0.07 * * \\
(0.02)\end{array}$ & $\begin{array}{l}0.17^{*} \\
(0.10)\end{array}$ & $\begin{array}{c}-0.08^{* *} \\
(0.02)\end{array}$ & $\begin{array}{c}-0.08^{* *} \\
(0.02)\end{array}$ & \\
\hline Constant & $\begin{array}{c}2.42 \\
(0.69)\end{array}$ & $\begin{array}{l}-0.35 \\
(1.16)\end{array}$ & $\begin{array}{l}2.31 * * \\
(0.81)\end{array}$ & $\begin{array}{l}2.68^{* *} \\
(0.88)\end{array}$ & $\begin{array}{c}3.0^{* *} \\
0.9\end{array}$ \\
\hline \multicolumn{6}{|l|}{ Diagnostic statistics } \\
\hline R-squared & 0.24 & 0.14 & - & - & - \\
\hline \# observations & 330 & 330 & 330 & 325 & 258 \\
\hline \# countries & 70 & 70 & 70 & 69 & 54 \\
\hline Countries excluded & & & & Jordan & $\begin{array}{l}\text { Industrial } \\
\text { countries }\end{array}$ \\
\hline Minimum \# observations per country & 2 & 2 & 2 & 2 & 3 \\
\hline Average \# observations per country & 4.7 & 4.7 & 4.7 & 4.7 & 4.8 \\
\hline Maximum \# observations per country & 5 & 5 & 5 & 5 & 5 \\
\hline Hansen test & - & - & 5.21 & 6.69 & 5.50 \\
\hline A-B test for AR(1) & - & - & $-3.26^{* *}$ & $-3.27 * *$ & $-3.14 * *$ \\
\hline A-B test for AR(2) & - & - & -1.12 & -1.09 & -0.92 \\
\hline \multicolumn{6}{|l|}{ Notes: } \\
\hline $\begin{array}{l}\text { Output growth volatility is the standarc } \\
\text { Robust standard errors are in parenthes } \\
\text { See Data appendix for variable definiti } \\
\text { A * denotes significance at the } 10 \text { perc } \\
\text { Period dummies are included in the est }\end{array}$ & $\begin{array}{l}\text { deviation of } \mathrm{re} \\
\text { s. } \\
\text { ns. } \\
\text { nt level and *: } \\
\text { mations. }\end{array}$ & $\begin{array}{l}\text { al GDP per capi } \\
\text { denotes signific }\end{array}$ & $\begin{array}{l}\text { a growth over } \\
\text { ance at the } 5 \mathrm{p}\end{array}$ & five year peri & \\
\hline
\end{tabular}


Table 6: Nonlinear Ordinary Least Squares and Instrumental Variables Regression Results

Dependent Variable is: Volatility of Output Growth, 1970 - 2004

\begin{tabular}{lccc}
\hline & OLS & OLS & IV \\
\hline Workers remittances to GDP(wrgdp)*dummy $=1$ if wrgdp $<=2 \%(\alpha)$ & $-1.41^{* *}$ & $-1.51^{* *}$ & $-1.34^{* *}$ \\
& $(0.51)$ & $(0.50)$ & $(0.41)$ \\
Workers remittances to GDP (wrgdp) *dummy $=1$ if wrgdp $>2 \%(\beta)$ & $-0.21^{* *}$ & $-0.35^{* *}$ & $-0.20^{* *}$ \\
& $(0.10)$ & $(0.12)$ & $(0.10)$ \\
Terms of trade volatility & $0.10^{* *}$ & $0.08^{*}$ & $0.12^{* *}$ \\
& $(0.05)$ & $(0.04)$ & $(0.05)$ \\
Trade openness to GDP & $0.01^{* *}$ & 0.01 & $0.01^{* *}$ \\
& $(0.01)$ & $(0.01)$ & $(0.01)$ \\
Primary commodity export composition & 0.01 & $0.02^{*}$ & 0.01 \\
& $(0.01)$ & $(0.01)$ & $(0.01)$ \\
Government consumption to GDP & $0.08^{* *}$ & 0.06 & $0.07^{* *}$ \\
& $(0.04)$ & $(0.04)$ & $(0.03)$ \\
Government consumption to GDP*industrial country dummy & $-0.08^{* *}$ & $-0.08^{* *}$ & $-0.07^{* *}$ \\
& $(0.03)$ & $(0.03)$ & $(0.03)$ \\
Constant & 1.33 & $2.14^{* *}$ & 1.36 \\
& $(0.98)$ & $(1.04)$ & $(0.97)$ \\
R-squared & 0.43 & 0.45 & 0.432 \\
Number of observations & 70 & 69 & 70 \\
F test $\alpha=\beta$ & $7.1^{* *}$ & $6.9^{* *}$ & $9.5^{* *}$ \\
Countries excluded & & Jordan & \\
\hline Notes: & & & \\
Output growth volatility is the standard deviation of real GDP per capita & & & \\
Robust standard errors are in parentheses. See Data appendix for variable definitions. & & \\
A * denotes significance at the 10 percent level and ** denotes significance at the 5 percent level. & \\
IV instruments the remittance to GDP ratio using the remittances to GDP ratio in the rest of the world. \\
\hline
\end{tabular}


Table 7: Nonlinear GMM System Estimation

Dependent Variable is: Volatility of Output Growth, 1980 - 2004

(5-year period observations)

Workers remittances to GDP(wrgdp) *dummy=1 if wrgdp

$<=2 \%$

$\begin{array}{ccc}-1.43 * * & -1.59 * * & -1.45 * * \\ (0.69) & (0.68) & (0.49) \\ -0.19 * * & -0.17 * * & -0.19 * \\ (0.09) & (0.08) & (0.11) \\ 0.10 * * & 0.10 * * & 0.09 * * \\ (0.03) & (0.03) & (0.03) \\ 0.011 & 0.01 & 0.00 \\ (0.008) & (0.01) & (0.01) \\ 0.03 * & 0.03 & 0.03 \\ (0.02) & (0.02) & (0.02) \\ -0.09 * * & -0.09 * * & \\ (0.02) & (0.02) & \\ 2.32 * * & 2.39 & 3.09 * * \\ (0.89) & (0.89) & 0.88\end{array}$

Diagnostic statistics

\# observations

$\begin{array}{lll}330 & 325 & 258\end{array}$

\# countries

$\begin{array}{lll}70 & 69 & 54\end{array}$

Minimum \# observations per country

Average \# observations per country

Maximum \# observations per country

2

4.7

2

54

5

4.71

4.78

Countries excluded

5

5

Industrial

Jordan countries

Hansen test

$\begin{array}{ccc}12.18 & 13.41 & 8.04 \\ -3.34^{* *} & -3.34^{* *} & -3.26^{* *} \\ -0.98 & -0.92 & -0.79\end{array}$

A-B test for $\operatorname{AR}(2)$

$-0.79$

Notes:

Output growth volatility is the standard deviation of real GDP per capita growth over five year periods.

Robust standard errors are in parentheses.

See Data appendix for variable definitions.

A * denotes significance at the 10 percent level and ** denotes significance at the 5 percent level. Period dummies are included in the estimations. 
Table 8: Estimated Impact of Remittances on Volatility

\begin{tabular}{ccccccc}
\hline & $\begin{array}{c}\text { Developing } \\
\text { Asia }\end{array}$ & $\begin{array}{c}\text { Industrial } \\
\text { countries }\end{array}$ & MENA & $\begin{array}{c}\text { Transition } \\
\text { countries }\end{array}$ & Africa & $\begin{array}{c}\text { Western } \\
\text { Hemisphere }\end{array}$ \\
\hline $1975-1979$ & -0.64 & -1.45 & -0.93 & & -0.7 & -0.43 \\
$1980-1984$ & -1.99 & -1.67 & -1.10 & & -0.8 & -0.56 \\
$1985-1989$ & -1.95 & -1.35 & -0.89 & 0 & -1.0 & -1.20 \\
$1990-1994$ & -2.13 & -1.02 & -0.80 & -0.08 & -1.2 & -2.39 \\
$1995-1999$ & -2.56 & -0.75 & -0.79 & -0.37 & -1.4 & -0.52 \\
$2000-2004$ & -0.54 & -0.52 & -0.86 & -0.71 & -2.8 & -0.88 \\
\hline
\end{tabular}




\section{Data Appendix}

This appendix provides the definition and data sources for the variables used in the regressions that are reported in the paper. It also defines the country groupings. With the exception of the output volatility and the terms of trade volatility variables, the data are averaged over the 1970-2004 period, unless otherwise indicated, for the cross-section OLS and IV regressions. For the variables that are included in the GMM dynamic panel estimations outside of the volatility variables, the data are averaged over non-overlapping five-year periods (1980-1984, 1985-1989, 1990-1994, 1995-1999, and 2000-2004).

\section{A. Data Definitions and Sources}

\section{Variables included in the preferred regression specification}

Volatility of per capita output growth is defined as the standard deviation of annual real GDP per capita growth over the 1970-2004 period in the OLS and IV cross-section regressions and over each 5-year period in the GMM estimations. Per capita real GDP growth is measured using data on real per capita GDP in constant dollars (international prices, base year 2000) obtained from the Penn World Tables (PWT), Version 6.2.

Workers remittances is the ratio of workers remittances to GDP. The source of the data is the World Bank's World Development Indicators.

Terms of trade volatility is measured as the standard deviation of the annual change in the terms of trade over the 1970-2004 period in the OLS and IV cross-section regressions and over each 5-year period in the GMM estimations. The source of the data is the IMF's WEO database.

Trade openness is defined as the sum of imports and exports of goods and services divided by GDP in constant 2000 prices. The source of the data is the Penn World Tables, Version 6.2.

The commodity export composition is the share of primary commodities in total exports. For each country, the average share of primary commodity exports in total exports over the 1999-2004 period is calculated. The calculations are based on information on 44 commodities. The source of the data is the UN Comtrade database.

Government consumption is the ratio of government consumption to GDP in constant 2000 prices. The source of the data is the Penn World Tables (PWT), Version 6.2.

Variables not included in the preferred regression specification

Relative income is the level of real per capita income relative to the United States (squared). The data on real per capita GDP in constant 2000 prices is obtained from Penn World Tables, Version 6.2. 
Relative income squared is the square of relative income.

Trade concentration ratio is the ratio of exports to a country's three largest trading partners in total exports. The source of the data is the IMF's Direction of Trade Statistics.

Financial openness is defined as the ratio of the stock of foreign liabilities and foreign assets to GDP. The source of the data is Lane and Milesi-Ferretti (2006).

Financial sector development is proxied by the average ratio of private sector credit to GDP. The source of the data is Beck, Demirgüç-Kunt, and Levine (2006).

Institutional quality is proxied by an indicator of bureaucracy quality - the strength and expertise of the bureaucracy to govern without drastic changes in policy or interruptions in government services. Alternative indicators of institutional quality also examined in the paper include the following: (1) an index of corruption - the degree of all forms of corruption such as patronage, nepotism, and suspiciously close ties between politics and business; (2) an index of the rule of law- the strength and impartiality of the legal system and the extent of popular observance of the law; and (3) an aggregate index of institutional quality constructed as the equally weighted average of the bureaucracy quality, corruption, and rule of law indices. The indices are reported in the International Country Risk Guide. Each index is constructed as the average over the 1984-2005 period. The indices are re-scaled from 1 to 12 , where high values indicate good institutions.

Volatility in discretionary fiscal spending is measured as the standard deviation of cyclically-adjusted government spending over the 1960-2000 period from Fatás and Mihov (2003).

\section{B. Country Coverage}

The section lists all the countries included in the paper. The set of countries included is determined by the availability of the data for all the explanatory variables.

\section{Industrial countries (16):}

Austria, Belgium, Cyprus, Denmark, Finland, France, Greece, Ireland, Italy, Japan, New Zealand, Norway, Portugal, Spain, Sweden, and the United States.

\section{Developing countries (54):}

\section{Africa}

Burkina Faso, Cameroon,Cote d'Ivoire, Ethiopia, Gabon, Ghana, Kenya, Madagascar, Malawi, Mali, Niger, Nigeria, Senegal, Togo, Uganda, and Zimbabwe.

Asia

India, Indonesia, Republic of Korea, Malaysia, Philippines, Sri Lanka, and Thailand. 
Middle East and North Africa

Egypt, Iran, Jordan, Malta, Morocco, Pakistan, Sudan, Syria, Tunisia, and Turkey.

Transition countries

Hungary and Poland.

Western Hemisphere

Argentina, Bolivia, Chile, Colombia, Costa Rica, Dominican Republic, Ecuador, El Salvador, Guatemala, Honduras, Jamaica, Mexico, Nicaragua, Panama, Papua New Guinea, Paraguay, Peru, Trinidad \& Tobago, and Venezuela. 


\section{References}

Abdih, Yasser, Ralph Chami, Jihad Dagher, and Peter Montiel, 2008, "Remittances and Institutions: Are Remittances a Curse?” IMF Working Papers 08/29 (Washington: International Monetary Fund).

Acemoglu, Daron, Simon Johnson, James Robinson, and Yunyong Thaicharoen, 2003, "Institutional Causes, Macroeconomic Symptoms: Volatility, Crises, and Growth," Journal of Monetary Economics, 50:1, pp. 49 - 123.

Bekaert, Geert, Campbell Harvey, and Christian Lundblad, 2006, "Growth Volatility and Financial Liberalization," Journal of International Money and Finance, 25, pp. 370 403.

Caballero, Ricardo, 2000, "Macroeconomic Volatility in Latin America: A Conceptual Framework and Three Case Studies," Economia, (Fall), pp. 31 - 107.

Calderon, Cesar, Normal Loayza, and Klaus Schmidt-Hebbel, 2005, "Openness, Vulnerability, and Growth," mimeo (April), (Washington: World Bank).

Cali, Massimiliano, Isabella Massa, and Dirk Wellem te Verde, 2008, "The Global Financial Crisis: Financial Flows Into Developing Countries Set to Fall by One Quarter," Overseas Development Institute.

Chami, R., A. Barajas, T. Cosimano, C. Fullenkamp, M. Gapen, and P. Montiel 2008, "Macroeconomic Consequences of Remittances", IMF Occasional Paper No 259 (Washington: International Monetary Fund).

Chami, R., T.F. Cosimano, and M.Gapen, 2006, "Beware of Emigrants Bearing Gifts: Optimal Fiscal and Monetary Policy in the Presence of Remittances," IMF Working Paper 06/61 (Washington: International Monetary Fund).

Chami, R., C. Fullenkamp, and S. Jahjah, 2003, "Are Immigrant Remittance Flows a Source of Capital for Development?" IMF Working Papers 03/189 (Washington: International Monetary Fund).

Easterly, Williams, Roumeen Islam, and Joseph Stiglitz, 2000, “Explaining Growth Volatility," World Bank, mimeo.

Easterly, William, Michael Kremer, and Lawrence H. Summers, 1993, "Good Policy or Good Luck? Country Growth Performance and Temporary Shocks," Journal of Monetary Economics, 32, pp. 459 - 483. 
Fatás, Antonio, and Ilian Mihov, 2003, "The Case for Restricting Fiscal Policy Discretion," Quarterly Journal of Economics, Vol. 118, No. 4, pp. 1419 - 48.

Furceri, Davide, and Georgios Karras, 2007, "Country Size and Business Cycle Volatility: Scale Really Matters," Journal of the Japanese and International Economies, 21, pp. $424-434$.

Hakura, Dalia, 2007, “Output Volatility and Large Output Drops in Emerging Market and Developing Countries,” IMF Working Paper 07/114 (Washington: International Monetary Fund).

International Monetary Fund, 2005, World Economic Outlook, April 2005: Globalization and External Imbalances, World Economic and Financial Surveys (Washington).

Koren, Miklos, and Sylvia Tenreyro, 2004, "Diversification and Development," mimeo.

Kose, M. Ayhan, Eswar Prasad, and Marco Terrones, 2003, "Financial Integration and Macroeconomic Volatility,” IMF Working Paper 03/50 (Washington: International Monetary Fund).

Kose, M. Ayhan, Eswar Prasad, Kenneth Rogoff, and Shang-Jin Wei 2006, "Financial Globalization: A Reappraisal," IMF Working Paper 06/189 (Washington: International Monetary Fund).

Mobarak, Ahmed Mushfiq, 2005, "Determinants of Volatility and Implications for Economic Development," Review of Economics and Statistics, Vol. 87, pp. 347 - 361.

Ratha, Dilip and Sanket Mohapatra, 2009, Migration and Development Brief, No. 9.

Rodrik, Dani, 1998, “Why Do More Open Economies Have Bigger Governments?” Journal of Political Economy, Vol. 106, No. 5, pp. 997 - 1032.

World Bank, 2006, Global Economic Prospects: Economic Implications of Remittances and Migration (Washington: The World Bank). 